\title{
Gut Microbiota and Environment in Coronary Artery Disease
}

\author{
Andrea Piccioni ${ }^{1, *} \mathbb{C}^{\mathbb{C}}$, Tommaso de Cunzo ${ }^{1}{ }^{(\mathbb{D}}$, Federico Valletta ${ }^{1}$, Marcello Covino ${ }^{1}$, Emanuele Rinninella ${ }^{2} \mathbb{D}$, \\ Pauline Raoul $^{3}{ }^{\circledR 0}$, Christian Zanza ${ }^{1}$, Maria Cristina Mele ${ }^{3,4} \oplus$ and Francesco Franceschi ${ }^{1}$
}

1 Department of Emergency Medicine, Fondazione Policlinico Universitario A. Gemelli IRCCS, Università Cattolica del Sacro Cuore, Largo A. Gemelli, 8, 00168 Rome, Italy; tomdecunzo@gmail.com (T.d.C.); fede.valletta@gmail.com (F.V.); marcello.covino@policlinicogemelli.it (M.C.); christian.zanza@live.it (C.Z.); francesco.franceschi@unicatt.it (F.F.)

2 UOC di Nutrizione Clinica, Dipartimento di Scienze Mediche e Chirurgiche, Fondazione Policlinico Universitario A. Gemelli IRCSS, 00168 Rome, Italy; emanuele.rinninella@unicatt.it

3 Dipartimento di Medicina e Chirurgia Traslazionale, Università Cattolica del Sacro Cuore, 00168 Rome, Italy; pauline.raoul1@gmail.com (P.R.); mariacristina.mele@unicatt.it (M.C.M.)

4 UOSD di Nutrizione Avanzata in Oncologia, Dipartimento di Scienze Mediche e Chirurgiche, Fondazione Policlinico Universitario A. Gemelli IRCSS, 00168 Rome, Italy

* Correspondence: andrea.piccioni@policlinicogemelli.it

Citation: Piccioni, A.; de Cunzo, T.; Valletta, F.; Covino, M.; Rinninella, E.; Raoul, P.; Zanza, C.; Mele, M.C.; Franceschi, F. Gut Microbiota and Environment in Coronary Artery Disease. Int. J. Environ. Res. Public Health 2021, 18, 4242. https:// doi.org/10.3390/ijerph18084242

Academic Editor: Paul B. Tchounwou

Received: 31 March 2021

Accepted: 14 April 2021

Published: 16 April 2021

Publisher's Note: MDPI stays neutral with regard to jurisdictional claims in published maps and institutional affiliations.

Copyright: (c) 2021 by the authors. Licensee MDPI, Basel, Switzerland. This article is an open access article distributed under the terms and conditions of the Creative Commons Attribution (CC BY) license (https:// creativecommons.org/licenses/by/ $4.0 /)$.
Abstract: In recent years, studies evaluated the associations between coronary artery disease (CAD) and fecal gut microbiota composition. This opens new perspectives on therapeutic strategies to prevent CAD representing the leading cause of mortality in Western societies. We have conducted a review of the literature regarding the characteristics of the gut microbiota of CAD patients, its underlying mechanisms and their associations with pollution and the Western diet. The latest evidence confirms that an abnormal microbiota predisposes to the development of CAD and differs in composition compared to the microbiota of healthy patients; the results are, however, heterogeneous. The most studied underlying mechanisms involve the production of trimethylamine-N-oxide (TMAO), the synthesis of short-chain fatty acids (SCFAs) and the immune system activation mediated by lipopolysaccharides (LPS). Despite a large amount of available data, there is no evidence about the role of a specific type of gut microbiota in the risk of developing acute coronary syndrome (ACS). Moreover, no relationship has been assessed between the gut microbiota and the characteristics of coronary plaques in humans. However, a close association has been found between both pollution and the Western diet and gut microbiota and CAD. Further studies are needed to clarify the associations between gut microbiota, $\mathrm{CAD}$, and ACS to find efficient therapeutic strategies.

Keywords: gut microbiota; coronary artery disease; trimethylamine-N-oxide; short-chain fatty acids; lipopolysaccharides; pollution; Western diet

\section{Introduction}

Coronary artery disease (CAD) is the leading cause of mortality in Western societies, affecting about one-third of the population before the age of seventy [1]. Over the past decades, several risk factors for CAD have been identified, including smoking, hypertension, hypercholesterolemia, diabetes, and obesity [2]. Despite the increasing ability to correct such factors, the incidence of heart diseases remains high and they still represent the major cause of mortality. Therefore, research has recently focused on finding new risk factors so as to identify alternative therapeutic strategies and prognostic indexes. Among these, the gut microbiota.

With a total of more than $10^{13}$ microorganisms, gut microbiota refers to the entire population of bacteria, archaea, viruses, and protozoans that colonize the intestinal tract, most of them within the large intestine, where there is over than $70 \%$ of all microbes found in the body. The predominant phyla are Firmicutes and Bacteroidetes followed by Proteobacteria and Actinobacteria. There are also pathogenic species such as Campylobacter jejuni, 
Salmonella enterica, Bacteroides fragilis, Vibrio cholera, and Escherichia coli, but in a low abundance (0.1\% or less) [3]. Bacteroides, Bifidobacterium, Streptococcus, Enterobacteriaceae, Enterococcus, Clostridium, Lactobacillus, and Ruminococcus are the predominant luminal microbial genera and they can be identified in stool [4].

Gut microbiota strongly varies depending on several environmental and lifestyle factors, such as pollution and diet [5-7], and maintains a symbiotic relationship with the gut mucosa, with substantial metabolic, immunological, and gut protective functions in the healthy individual [8-11].

In recent years, diseases such as inflammatory bowel disease [12], asthma [13], depression [14], and Hashimoto's thyroiditis [15] have been associated with the composition of the gut microbiota. However, research has also focused on heart diseases, and gut microbiota has been shown to affect the cardiovascular system through different mechanisms, representing a potentially modifiable risk factor for atherosclerosis. This opens new perspectives on therapeutic and preventive strategies for CAD.

The hypothesis that microorganisms can influence coronary atherosclerosis was first proposed a long time ago, when, in 1978, Fabricant et al. demonstrated that Marek's herpes virus could cause atherosclerosis in chickens [16]. They subsequently observed that such an atherosclerotic effect could be prevented by vaccination, thus revealing the therapeutic potential of these experiments [17]. Since then, many microorganisms have been associated with coronary atherosclerosis, and some of them are also thought to act with a direct mechanism: the presence of bacterial deoxyribonucleic acid (DNA) in human atherosclerotic plaques has been demonstrated, especially of microorganisms from the oral cavity $[18,19]$ or the respiratory tract [20]. In other cases, microorganisms such as HIV or Helicobacter Pylori can cause chronic inflammation that predisposes to the development of atherosclerosis [21,22].

In this review, we provide an update of the literature about the associations between gut microbiota and cardiovascular disease, focusing on CAD and highlighting possible associations of pollution and diet, microbiota and CAD.

\section{Methods}

A literature research was performed in PubMed and Google Scholar electronic databases, using the following keywords: "gut microbiota", "atherosclerosis", "coronary artery disease", ST elevation myocardial infarction ("STEMI"), "metabolism", "inflammation", "trimethylamine N-oxide", "TMAO", "SCFA", "LPS", "pollution", "diet", "carnitine", "meat", "choline". Only English-language articles were included, and preference was given to papers published within the last 10 years. We have searched the bibliographies of the selected articles to identify other relevant articles. We have excluded studies over 10 years old, inappropriate or not relevant topics to the specific focus of this review.

\section{Results}

Forty-five studies assessing the associations between gut microbiota and cardiovascular disease were included. Tables 1-4 describe the study design, year of publication, subjects evaluated and the main findings. 
Table 1. Studies on gut microbiota composition in CAD patients.

\begin{tabular}{|c|c|c|c|c|}
\hline Authors & Study Design & Year & Subjects & Findings \\
\hline Fialho A. et al. [23] & Observational & 2018 & $\begin{array}{l}160 \text { patients who underwent } \\
\text { coronary angiography }\end{array}$ & Patients with SIBO had a higher frequency of CAD \\
\hline Karlsson F.H. et al. [24] & Comparative & 2012 & $\begin{array}{l}12 \text { patients with symptomatic } \\
\text { atherosclerotic plaques and } 13 \\
\text { healthy patients }\end{array}$ & $\begin{array}{c}\text { Symptomatic atherosclerosis is associated with } \\
\text { Collinsella. Eubacterium and Roseburia are predominant } \\
\text { in the control group }\end{array}$ \\
\hline Emoto T. et al. [25] & Comparative & 2016 & $\begin{array}{l}39 \mathrm{CAD} \text { patients and } 50 \text { healthy } \\
\text { volunteers }\end{array}$ & $\begin{array}{l}\text { CAD patients have an increase in Lactobacillales and a } \\
\text { reduction of phylum Bacteroidetes }\end{array}$ \\
\hline Zhu Q. et al. [26] & Comparative & 2018 & $\begin{array}{l}\text { 70 CAD patients and } 98 \text { healthy } \\
\text { controls }\end{array}$ & $\begin{array}{l}\text { CAD patients have an increase in Faecalibacterium, } \\
\text { Subdoligranum, Roseburia and Eubacterium and a } \\
\text { reduction of Escherichia, Shigella and Enterococcus }\end{array}$ \\
\hline Kelly T.N. et al. [27] & $\begin{array}{l}\text { Long-term } \\
\text { epidemiologic }\end{array}$ & 2016 & 112 participants & $\begin{array}{l}\text { Participants who developed a high cardiovascular } \\
\text { disease risk have an increase in Prevotella and Tyzzerella }\end{array}$ \\
\hline Li J. et al. [28] & Comparative & 2017 & $\begin{array}{l}155 \text { patients with } \\
\text { pre-hypertension or primary } \\
\text { hypertension and } 41 \text { healthy } \\
\text { controls }\end{array}$ & $\begin{array}{c}\text { Patients with primary hypertension have an increase in } \\
\text { Prevotella and Klebsiella and a reduction of } \\
\text { Faecalibacterium, Oscillibacter, Roseburia, Bifidobacterium, } \\
\text { Coprococcus, and Butyrivibrio }\end{array}$ \\
\hline Cui L. et al. [29] & Comparative & 2017 & $\begin{array}{l}29 \text { CAD patients and } 35 \text { healthy } \\
\text { controls }\end{array}$ & $\begin{array}{c}\text { CAD patients have an increase in phyla Firmicutes and } \\
\text { Fusobacteria and a reduction of Bacteroidetes and } \\
\text { Proteobacteria }\end{array}$ \\
\hline Yoshida N. et al. [30] & Comparative & 2018 & $\begin{array}{l}30 \text { CAD patients and } 30 \text { healthy } \\
\text { controls }\end{array}$ & $\begin{array}{c}\text { CAD patients have a reduction of Bacteroides vulgatus } \\
\text { and Bacteroides dorei. Treatment with with these two } \\
\text { species attenuated atherosclerotic lesion formation in } \\
\text { atherosclerosis-prone mice }\end{array}$ \\
\hline Toya T. et al. [31] & Comparative & 2020 & $\begin{array}{l}53 \text { advanced CAD patients and } \\
53 \text { healthy controls }\end{array}$ & $\begin{array}{c}\text { CAD patients have an increase in Ruminococcus gnavus } \\
\text { and a reduction of Lachnospiraceae NK4B4 and } \\
\text { Ruminococcus gauvreauii }\end{array}$ \\
\hline
\end{tabular}

Abbreviations: CAD, coronary artery disease.

Table 2. Studies on the association between TMAO and cardiovascular disease.

\begin{tabular}{|c|c|c|c|c|}
\hline Authors & Type & Year & Subjects & Findings \\
\hline Stubbs J.R. et al. [32] & Prospective & 2016 & $\begin{array}{l}220 \text { patients with chronic kidney } \\
\text { disease who underwent } \\
\text { coronary angiography }\end{array}$ & $\begin{array}{l}\text { Increased TMAO concentrations correlate with } \\
\text { coronary atherosclerosis burden }\end{array}$ \\
\hline Li X.S. et al. [33] & $\begin{array}{l}\text { Metabolomics } \\
\text { analyses }\end{array}$ & 2018 & $\begin{array}{l}\text { CAD patients and healthy } \\
\text { controls }\end{array}$ & $\begin{array}{c}\text { The levels of trimethyllysine, a nutrient precursor } \\
\text { of TMAO, are associated with major adverse } \\
\text { cardiovascular event risks }\end{array}$ \\
\hline Lent-Schochet D. et al. [34] & Comparative & 2018 & $\begin{array}{l}30 \text { patients with metabolic } \\
\text { syndrome and } 20 \text { healthy } \\
\text { controls }\end{array}$ & TMAO levels increase in metabolic syndrome \\
\hline Randrianarisoa E. et al. [35] & Prospective & 2016 & 220 patients & $\begin{array}{l}\text { TMAO levels are positively associated with } \\
\text { visceral fat mass and liver fat content and } \\
\text { negatively associated with insulin sensitivity and } \\
\text { carotid intima-media thickness }\end{array}$ \\
\hline Haghikia A. et al. [36] & Prospective & 2018 & $\begin{array}{l}\text { Two prospective cohorts of } \\
\text { patients with first-ever ischemic } \\
\text { stroke }\end{array}$ & $\begin{array}{l}\text { TMAO levels are linked with an increased risk of } \\
\text { myocardial infarction, recurrent stroke and } \\
\text { cardiovascular death }\end{array}$ \\
\hline Matsuzawa Y. et al. [37] & Observational & 2019 & 112 STEMI patients & $\begin{array}{l}\text { TMAO levels are a significant and independent } \\
\text { predictor of future cardiovascular events in } \\
\text { patients after STEMI }\end{array}$ \\
\hline Li X.S. et al. [38] & Multicenter & 2019 & $\begin{array}{l}530 \text { and } 1053 \text { patients with } \\
\text { suspected ACS }\end{array}$ & $\begin{array}{l}\text { TMAO levels are associated with both near- and } \\
\text { long-term CV events in patients with chest pain } \\
\text { and ACS }\end{array}$ \\
\hline Gao J. et al. [39] & Prospective & 2020 & $\begin{array}{l}30 \text { patients with unstable angina } \\
\text { pectoris, } 30 \text { post-STEMI and } 30 \\
\text { healthy controls }\end{array}$ & Elevated serum TMAO levels correlated with ACS \\
\hline Tascanov M.B. et al. [40] & Prospective & 2020 & $\begin{array}{l}44 \text { young patients with ACS }(<50 \\
\text { years of age), } 39 \text { elderly patients } \\
\text { with ACS, and } 44 \text { healthy control }\end{array}$ & $\begin{array}{c}\text { Young patients with ACS had significantly higher } \\
\text { levels of TMAO compared to the control and } \\
\text { elderly ACS groups }\end{array}$ \\
\hline Seldin M.M. et al. [41] & Prospective & 2016 & $\begin{array}{l}\text { Mice with chronic dietary } \\
\text { TMAO supplementation }\end{array}$ & $\begin{array}{l}\text { TMAO activates inflammatory pathways in cells } \\
\text { of the vasculature, leading to atherosclerosis }\end{array}$ \\
\hline Ma G. et al. [42] & Prospective & 2017 & $\begin{array}{l}\text { Mice with chronic dietary } \\
\text { choline supplementation }\end{array}$ & $\begin{array}{l}\text { TMAO promotes cell adhesion molecule- } 1 \\
\text { (VCAM-1) expression and monocyte adherence }\end{array}$ \\
\hline Chen M.L. et al. [43] & Prospective & 2017 & $\begin{array}{l}\text { Mice with chronic dietary } \\
\text { choline supplementation }\end{array}$ & $\begin{array}{l}\text { TMAO promotes vascular inflammation by } \\
\text { activating the NLRP3 inflammasome }\end{array}$ \\
\hline
\end{tabular}


Table 2. Cont.

\begin{tabular}{|c|c|c|c|c|}
\hline Authors & Type & Year & Subjects & Findings \\
\hline Geng J. et al. [44] & Prospective & 2018 & $\begin{array}{l}\text { Mice with chronic dietary } \\
\text { TMAO supplementation }\end{array}$ & $\begin{array}{l}\text { TMAO promotes the atherosclerosis via } \\
\text { CD36/MAPK/JNK pathway }\end{array}$ \\
\hline Koeth R.A. et al. [45] & Prospective & 2013 & $\begin{array}{l}\text { Mice with chronic dietary } \\
\text { L-carnitine supplementation }\end{array}$ & $\begin{array}{c}\text { L-carnitine produces TMAO that modulates } \\
\text { cholesterol and sterol metabolism and increases } \\
\text { atherosclerosis }\end{array}$ \\
\hline Wang et al. [46] & Prospective & 2011 & $\begin{array}{l}\text { Mice with chronic dietary } \\
\text { choline, TMAO or betaine } \\
\text { supplementation }\end{array}$ & $\begin{array}{c}\text { TMAO promotes the up regulation of multiple } \\
\text { macrophage scavenger receptors linked to } \\
\text { atherosclerosis }\end{array}$ \\
\hline Chen M.L. et al. [47] & $\begin{array}{l}\text { Randomized } \\
\text { controlled } \\
\text { trial }\end{array}$ & 2016 & Mice treated with resveratrol & $\begin{array}{l}\text { Resveratrol decreases TMAO levels and increases } \\
\text { hepatic biliar acids neosynthesis }\end{array}$ \\
\hline Ding L. et al. [48] & Prospective & 2018 & $\begin{array}{l}\text { Mice with chronic dietary } \\
\text { TMAO supplementation }\end{array}$ & $\begin{array}{l}\text { TMAO accelerates aortic lesion formation in mice } \\
\text { by altering bile acid profiles }\end{array}$ \\
\hline Zhu W. et al. [49] & Prospective & 2016 & $\begin{array}{l}\text { Mice with chronic dietary } \\
\text { TMAO supplementation }\end{array}$ & $\begin{array}{c}\text { TMAO directly enhances human platelet } \\
\text { responsiveness }\end{array}$ \\
\hline Skye S.M. et al. [50] & $\begin{array}{l}\text { Randomized } \\
\text { controlled } \\
\text { trial }\end{array}$ & 2018 & $\begin{array}{l}\text { Mice transplanted with human } \\
\text { microbiota from a low or high } \\
\text { TMAO donor }\end{array}$ & $\begin{array}{c}\text { Humanized mouse with high TMAO microbiome } \\
\text { has an increased platelet reactivity and thrombosis } \\
\text { potential }\end{array}$ \\
\hline Shih D.M. et al. [51] & Prospective & 2019 & FMO3 knockout mouse & $\begin{array}{l}\text { FMO3 knockout mice have a reduction of TMAO } \\
\text { accompanied by decreased platelet responsiveness }\end{array}$ \\
\hline Roberts A.B. et al. [52] & Prospective & 2018 & $\begin{array}{l}\text { Mice with chronic dietary } \\
\text { choline supplementation }\end{array}$ & $\begin{array}{l}\text { Inhibition of gut microbial TMA and TMAO } \\
\text { production reduces thrombosis potential }\end{array}$ \\
\hline
\end{tabular}

Abbreviations: ACS, acute coronary syndrome; CAD, coronary artery disease; CV, cardiovascular; FMO3, Flavin Containing Dimethylaniline Monoxygenase 3; STEMI, ST-Elevation Myocardial Infarction; TMA, trimethylamine; TMAO, trimethylamine-N-oxide.

Table 3. Studies on the association between SCFAs and cardiovascular disease.

\begin{tabular}{|c|c|c|c|c|}
\hline Authors & Type & Year & Subjects & Findings \\
\hline McNelis J.C. et al. [53] & Prospective & 2015 & GPR43 knockout mice & $\begin{array}{l}\text { SCFA/GPR43 system can regulate the process of } \\
\beta \text {-cell compensation in the insulin-resistant state }\end{array}$ \\
\hline den Besten G. et al. [54] & Prospective & 2015 & $\begin{array}{l}\text { Mice with chronic dietary } \\
\text { SCFA supplementation }\end{array}$ & $\begin{array}{l}\text { SCFAs protect against obesity and improved } \\
\text { insulin sensitivity through downregulation of } \\
\text { PPAR } \gamma\end{array}$ \\
\hline Vinolo M.A. et al. [55] & Prospective & 2011 & $\begin{array}{l}\text { Mice with chronic dietary } \\
\text { SCFA supplementation }\end{array}$ & $\begin{array}{l}\text { SCFAs inhibit production of proinflammatory } \\
\text { cytokines by LPS-stimulated neutrophils }\end{array}$ \\
\hline Aguilar E.C. et al. [56] & Prospective & 2014 & $\begin{array}{l}\text { Mice with chronic dietary } \\
\text { butyrate supplementation }\end{array}$ & $\begin{array}{c}\text { Butyrate can slow the progression of atherosclerosis } \\
\text { by reducing adhesion and migration of } \\
\text { macrophages and increasing plaque stability. }\end{array}$ \\
\hline
\end{tabular}

Abbreviations: GPR43, G-protein-coupled receptor 43; SCFA, short chain fatty acid.

Table 4. Studies on the association between LPS and cardiovascular disease.

\begin{tabular}{|c|c|c|c|c|}
\hline Authors & Type & Year & Subjects & Findings \\
\hline Ostos M.A. et al. [57] & Prospective & 2002 & $\begin{array}{l}\text { ApoE-deficient mice injected } \\
\text { with LPS }\end{array}$ & $\begin{array}{c}\text { LPS administration aggravates atherosclerosis in } \\
\text { apoE-deficient mice }\end{array}$ \\
\hline Geng S. et al. [58] & Prospective & 2016 & $\begin{array}{l}\text { ApoE-deficient mice injected } \\
\text { with LPS }\end{array}$ & $\begin{array}{l}\text { LPS causes significant elevation of pro-inflammatory } \\
\text { cytokines such as TNF- } \alpha \text { and IL- } 6\end{array}$ \\
\hline Zhou X. et al. [59] & Comparative & 2018 & $\begin{array}{l}50 \text { CAD patients, } 50 \text { STEMI } \\
\text { patients and } 49 \text { healthy control }\end{array}$ & $\begin{array}{l}\text { LPS in STEMI patients was significantly increased } \\
\text { maybe for a gut bacterial translocation into systemic } \\
\text { circulation }\end{array}$ \\
\hline Kasahara K. et al. [60] & Prospective & 2017 & ApoE-deficient mice & $\begin{array}{c}\text { ApoE- deficient mice are resistant to the development } \\
\text { of atherosclerosis and this is associated with a reduction } \\
\text { of LPS }\end{array}$ \\
\hline Fuijkschot W.W. et al. [61] & Prospective & 2018 & $\begin{array}{l}\text { ApoE-deficient mice injected } \\
\text { with LPS }\end{array}$ & $\begin{array}{c}\text { LPS injection triggers a systemic inflammation, but does } \\
\text { not increase atherosclerotic plaque area or } \\
\text { inflammatory cell density }\end{array}$ \\
\hline $\begin{array}{l}\text { Anzulovic-Mirosevic D. } \\
\text { et al. [62] }\end{array}$ & Comparative & 2011 & $\begin{array}{l}37 \text { patients with left ventricular } \\
\text { dysfunction, } 7 \text { acute myocardial } \\
\text { infarction and } 29 \text { healthy } \\
\text { controls }\end{array}$ & $\begin{array}{l}\text { LPS levels were lower in patients with a chronic left } \\
\text { ventricular dysfunction but without reaching any } \\
\text { statistical significance }\end{array}$ \\
\hline
\end{tabular}


Table 1 summarizes nine studies [23-31,63] evaluating the gut microbiota composition in CAD patients. Most of them are comparative studies [24-26,28-31,63]. All studies found that the microbiota composition of CAD patients differed from that of healthy controls, although the results are not always overlapping and potential causal relationships are challenging [64].

Table 2 details twenty-one studies [32-52] assessing the association between atherosclerosis and TMAO synthesis. A TMAO increase was found in patients with cardiovascular disease. Prospective studies in mice [41-46,48-52] have shown that TMAO has proinflammatory, prothrombotic and dyslipidemic effects.

Tables 3 and 4 summarize, respectively, four and six studies reporting the association of SCFAs and LPS with gut microbiota. SCFAs play a protective role against atherosclerosis while LPS activates systemic inflammation and accelerates the formation of the atherosclerotic plaques.

Table 5 details five studies about the connection between pollution and gut microbiota. Those point out that pollution can influence cardiovascular disease despite changes in the microbiota, opening new perspectives on prognostic and therapeutic strategies for these diseases.

Table 5. Studies on the association between pollution, gut microbiota and cardiovascular disease.

\begin{tabular}{|c|c|c|c|c|}
\hline Authors & Type & Year & Subjects & Findings \\
\hline Zhang S. et al. [65] & Observational & 2015 & Mice exposed to low doses of $\mathrm{Cd}$ & $\begin{array}{l}\text { Cadmium exposure alters the gut } \\
\text { microflora composition and increases LPS } \\
\text { production }\end{array}$ \\
\hline Li X. et al. [66] & Prospective & 2019 & $\begin{array}{c}\text { Mice treated with Cadmium or } \\
\text { Arsenic }\end{array}$ & $\begin{array}{c}\text { Cadmium and arsenic cause a depletion } \\
\text { of Bacteroides and affect bile acids } \\
\text { production }\end{array}$ \\
\hline Jin C. et al. [67] & Prospective & 2018 & $\begin{array}{l}\text { Mice with chronic exposure to } \\
\text { carbendazim }\end{array}$ & $\begin{array}{l}\text { Chronic carbendazim exposure induces } \\
\text { gut microbiota dysbiosis and disturbs } \\
\text { lipid metabolism }\end{array}$ \\
\hline Mutlu E.A. et al. [68] & Prospective & 2018 & $\begin{array}{c}\text { Mice exposed to particulate } \\
\text { matters }\end{array}$ & $\begin{array}{c}\text { Exposure to particulate matters alters gut } \\
\text { microbiota and induces inflammation in } \\
\text { the GI tract }\end{array}$ \\
\hline Fitch M.N. et al. [69] & Prospective & 2020 & $\begin{array}{l}\text { Mice exposed to wood-smoke } \\
\text { (WS) and mixed diesel and } \\
\text { gasoline vehicle exhaust (MVE) }\end{array}$ & $\begin{array}{c}\text { Inhalation exposure to WS or MVE alters } \\
\text { gut microbiota and increases markers of } \\
\text { an inflammatory response }\end{array}$ \\
\hline
\end{tabular}

Finally, Table 6 details the studies assessing the relationship between microbiota, diet and CAD.

Table 6. Studies on the association between diet, gut microbiota and cardiovascular disease.

\begin{tabular}{|c|c|c|c|c|}
\hline Authors & Type & Year & Subjects & Findings \\
\hline & & & 345 adults with or without & $\begin{array}{l}\text { Faecalibacterium prausnitzii in the absence of SCA and } \\
\text { Escherichia coli in the presence of SCA are directly } \\
\text { related to over-representation of metagenomic } \\
\text { pathways linked to different dietary sources: }\end{array}$ \\
\hline Baragetti et al. [70] & Observational & 2021 & $\begin{array}{l}\text { subclinical carotid atherosclerosis } \\
\text { (SCA) }\end{array}$ & $\begin{array}{l}\text { - Sulfur oxidation and starch degradation in } \\
\text { absence of SCA; } \\
\text { - } \\
\text { Metabolism of amino acids, syntheses of palmitate, } \\
\text { choline, carnitines and TMAO in presence of SCA }\end{array}$ \\
\hline De Filippis et al. [71] & Observational & 2016 & $\begin{array}{c}153 \text { Italian healthy adults (51 } \\
\text { vegetarians, } 51 \text { vegans and } 51 \\
\text { omnivores) }\end{array}$ & $\begin{array}{l}\text { - Habitual vegetarian and vegan diets promote } \\
\text { enrichment of fibre-degrading bacteria in the gut; } \\
\text { - Subjects who consume a Mediterranean diet rich } \\
\text { in fruit, legumes and vegetables have higher } \\
\text { levels of SCFAs; } \\
\text { Low adherence to the Mediterranean diet } \\
\text { corresponds to an increase in urinary TMAO } \\
\text { levels, a potential risk factor for cardiovascular } \\
\text { disease. }\end{array}$ \\
\hline
\end{tabular}


Table 6. Cont.

\begin{tabular}{|c|c|c|c|c|}
\hline Authors & Type & Year & Subjects & Findings \\
\hline Koeth et al. [45] & Mice model & 2013 & $\begin{array}{l}\text { Mice on either normal chow }(n=10) \\
\text { or carnitine supplemented diet } \\
\qquad(n=11)\end{array}$ & $\begin{array}{l}\text { Chronic dietary L-carnitine supplementation } \\
\text { significantly altered microbial composition, markedly } \\
\text { enhanced synthesis of TMA/TMAO, and increased } \\
\text { atherosclerosis, but not following suppression of } \\
\text { intestinal microbiota. }\end{array}$ \\
\hline Koeth et al. [72] & Observational & 2019 & $\begin{array}{l}32 \text { vegans/vegetarians volunteers } \\
\text { and } 40 \text { omnivores volunteers }\end{array}$ & $\begin{array}{l}\text { Dietary l-carnitine is converted into the atherosclerosis- } \\
\text { and thrombosis-promoting metabolite TMAO via } 2 \\
\text { sequential gut microbiota-dependent transformations: } \\
\text { (a) initial rapid generation of the atherogenic } \\
\text { intermediate } \gamma \mathrm{BB} \text {, followed by (b) transformation into } \\
\text { TMA via low-abundance microbiota in omnivores, and } \\
\text { to a markedly lower extent, in vegans/vegetarians.Gut } \\
\text { microbiota } \gamma \mathrm{BB} \rightarrow \mathrm{TMA} / \mathrm{TMAO} \text { transformation is } \\
\text { induced by omnivorous dietary patterns and chronic } \\
\text { l-carnitine exposure. }\end{array}$ \\
\hline Tang et al. [73] & Prospective & 2013 & $\begin{array}{l}\text { First study: } 40 \text { healthy adults } \\
\text { ingesting deuterium-labeled } \\
\text { phosphatidylcholine and two } \\
\text { hard-boiled eggsSecond study: } 4007 \\
\text { adults who underwent diagnostic } \\
\text { cardiac catheterization }\end{array}$ & $\begin{array}{l}\text { The production of TMAO from dietary } \\
\text { phosphatidylcholine is dependent on metabolism by } \\
\text { the gut microbiota. Pathways that are dependent on the } \\
\text { gut microbiota may contribute to the pathophysiology } \\
\text { of atherosclerotic CAD. }\end{array}$ \\
\hline Organ et al. [74] & $\begin{array}{l}\text { Controlled } \\
\text { mice model }\end{array}$ & 2016 & $\begin{array}{l}\text { Mice fed either a control diet, a diet } \\
\text { containing choline, a diet } \\
\text { containing TMAO }\end{array}$ & $\begin{array}{l}\text { Choline diet and its gut microbiota derived metabolite, } \\
\text { TMAO, exacerbate pressure overload-induced hear } \\
\text { failure. }\end{array}$ \\
\hline Park et al. [75] & $\begin{array}{l}\text { Randomized, } \\
\text { crossover } \\
\text { study }\end{array}$ & 2019 & & $\begin{array}{l}\text { Elevated TMAO levels were observed over a } 4 \text {-week } \\
\text { interval in individuals consuming a high-fat diet (HFD) } \\
\text { that is predominantly animal based, compared to } \\
\text { individuals consuming a low fat and the MD }\end{array}$ \\
\hline Marques et al. [76] & $\begin{array}{l}\text { Controlled } \\
\text { mice model }\end{array}$ & 2017 & $\begin{array}{l}\text { Mice fed with a control diet or } \\
\text { high-fiber diet, or acetate } \\
\text { supplementation. }\end{array}$ & $\begin{array}{l}\text { Fiber and acetate changed the gut microbiota } \\
\text { composition, increasing the prevalence of } \\
\text { acetate-producing bacteria, improving the levels of } \\
\text { Bacteroides acidifaciens, and decreasing gut } \\
\text { dysbiosis.Dietary intake of fiber and supplementation } \\
\text { with acetate modulated renal and cardiac molecular } \\
\text { pathways beneficial for cardiovascular function, } \\
\text { lowered blood pressure, decreased cardiac hypertrophy } \\
\text { and fibrosis, and improved heart function in } \\
\text { experimental hypertension. }\end{array}$ \\
\hline
\end{tabular}

\section{Gut Microbiota Composition in CAD Patients}

Considering these observations, in recent years, research has been focusing on the association between coronary atherosclerosis and gut microbiota composition. Although a close relationship between gut microbiota and atherosclerotic plaque formation has not yet been demonstrated, the latest evidence confirms that an abnormal microbiota predisposes to the development of CAD [23] and that gut bacterial composition differs in CAD patients compared with healthy patients; the results are, however, not homogeneous in terms of specific differences. A study analyzed fecal metagenomes of 12 patients with symptomatic atherosclerotic plaques showing an increase in the abundance of Collinsella and a reduction in the abundance of Eubacteria, Roseburia and Bacteroides species compared with the control group [24]. Emoto et al. reported an increase in Lactobacillales and a reduction in the abundance of Bacteroidetes phylum (Bacteroides + Prevotella) in CAD patients [25]. Another comparative study conducted by Zhu et al. reported a significant enrichment of Faecalibacterium, Subdoligranum, Roseburia and Eubacterium, while Escherichia, Shigella and Enterococcus abundances were reduced in CAD patients, hypothesizing that this bacterium plays an anti-inflammatory role [26]. A long-term epidemiologic study, using collected measures of systolic blood pressure, LDL cholesterol, and glucose to establish the cardiovascular risk, revealed that the growth of Prevotella 2, Prevotella 7, Tyzzerella and Tyzzerella 4 were associated with high cardiovascular disease risk while Alloprevotella and Catenibacterium were associated with low risk [27]. Li et al. found an overall reduction of microbial richness and diversity, a depletion in abundances of Faecalibacterium, Oscillibacter, 
Roseburia, Bifidobacterium, Coprococcus, and Butyrivibrio and an overgrowth of bacteria such as Prevotella and Klebsiella in patients with primary hypertension, one of the most important risk factors for CAD [28]. More recent studies used the $16 \mathrm{~S}$ ribosomal RNA sequencing for the identification of operational taxonomic units (OTUs) through which microorganisms are classified and then identified [63]. Using this technique, Cui et al. observed a decrease in Bacteroidetes and Proteobacteria phyla in CAD patients, whereas the phyla Firmicutes and Fusobacteria were increased [29]. Yoshida et al. reported the reduction of Bacteroides vulgatus and Bacteroides dorei in CAD, assuming that this is due to a higher systemic inflammatory effect that in healthy patients is inhibited by these two species [30]. Toya et al. showed a reduction of overall bacterial richness and evenness, an increase in Ruminococcus gnavus abundance, and a depletion in Lachnospiraceae NK4B4 and Ruminococcus gauvreauii levels in the gut microbiota of CAD patients [31].

\section{TMAO, Microbiota, and CAD}

One of the most studied mechanisms behind the association between gut microbiota and cardiovascular diseases involves TMAO. When large quantities of choline, carnitine, betaine, and other choline-containing compounds are ingested, intestinal bacteria degrade them into trimethylamine (TMA) which passes into the portal circulation and is then metabolized in TMAO by flavin-containing monooxygenase (FMO) enzyme in the liver [64]. Several studies have shown a direct correlation between TMAO levels and coronary atherosclerosis $[32,33]$. In fact, TMAO has a positive correlation with metabolic syndrome [34] and with age, BMI, total and LDL cholesterol, apolipoprotein B levels and tumor necrosis factor (TNF) alpha levels [35]. TMAO increases the risk of ventricular arrhythmia in stroke patients [36]. Even the most recent studies have confirmed the use of TMAO levels as a prognostic marker for cardiovascular disease [37,38]. In a prospective study conducted on 60 patients with STEMI or unstable angina, Gan et al. showed a direct correlation between TMAO levels and acute coronary syndrome (ACS) [39]. Tascanov et al. confirmed this association in a cohort of young ACS patients (age < 50 years) [40].

The mechanism through which TMAO promotes atherosclerosis is not yet known, but studies suggest that inflammation plays a central role. Seldin et al. found an activation of nuclear factor- $\mathrm{B}$ (NF- $\mathrm{kB}$ ) signaling and an enhancement of endothelial recruitment of leukocytes [41]. Ma et al. confirm these results and suggested that TMAO up-regulates vascular cell adhesion molecule-1 (VCAM-1) expression and promotes monocyte adherence [42]. Chen et al. demonstrated that TMAO promotes vascular inflammation in mice by activating nucleotide-binding oligomerization domain-like receptor family pyrin domain containing 3 (NLRP3) inflammasome [43]. TMAO also increases the expression of CD36 via the MAPK/JNK pathway, thus promoting atherosclerosis [44].

In addition to the inflammatory mechanism, in recent years, a metabolic role of TMAO has also been investigated. TMAO reduces the reverse cholesterol transport, through which cholesterol is transported from peripheral tissues to the liver and small intestine, and increases macrophage scavenger receptor A and CD36 surface expression and foam cell formation $[45,46]$. In a trial conducted by Chen et al., the administration of resveratrol to mice inhibited TMAO production, enhancing bile acid neosynthesis in the liver [47]. In a more recent study, Ding et al. found an activation of nuclear receptor farnesoid $X$ receptor (FXR) and small heterodimer partner (SHP) mediated by TMAO that suppresses CYP7A1 expression and ultimately inhibits bile acid synthesis, increasing fat mass, serum lipid concentrations and atherosclerosis [48].

TMAO may also have a prothrombotic effect. In a murine model proposed by Zhou et al., it promotes platelet responsiveness by enhancing the stimulus-dependent release of Ca2+ from intracellular Ca2+ stores [49]. These observations have been confirmed by a trial conducted by Skye et al. in which a transplant of human feces with a prothrombotic phenotype to a germ-free mouse was performed [50]. Shih et al. has recently proved that lower TMAO levels observed in FMO3 knockout mice were accompanied by decreased 
platelet responsiveness [51]. Roberts et al. suggested the use of drugs that inhibit TMAO to reduce thrombotic potential [52].

\section{SCFAs, Microbiota, and CAD}

Gut microbiota can also play a protective role against coronary atherosclerosis through the synthesis of SCFAs. SCFAs are the main products of intestinal fermentation of dietary fibers, and acetate, propionate, and butyrate are the most abundant [77]. These SCFAs can bind to a lot of G-protein coupled receptors (GPR) and may have an anti-inflammatory and immunomodulatory effect depending on this bond. Acetate is produced by many intestinal bacteria while only a few members of the families Veillonellaceae and Lachnospiraceae are propionic acid-producing bacteria, and butyrate is synthesized by Coprococcus, Faecalibacterium, Eubacterium, and Roseburia [78]. McNelis et al. demonstrated that SCFAs in mice protect against diet-induced-obesity and improve glucose and lipid metabolism through the bond with GPR43/FFAR2 and GPR41/FFAR3 [53]. Another experiment conducted on mice by den Besten et al. showed that butyrate and propionate reduce body weight and liver triglyceride accumulation through activation of peroxisome proliferator-activated receptor- $\gamma(\operatorname{PPAR} \gamma)$ [54]. Vinolo et al. showed a general reduction of cytokine release mediated by SCFA [55], and Aguilar et al. found a reduction of atherosclerotic plaque in mice after oral butyrate administration [56]. Although all these studies highlight the protective role of SCFA on atherosclerosis and inflammation, human studies are still lacking.

\section{LPS, Microbiota, and CAD}

Gut microbiota can trigger the immune system and atherosclerosis through Tolllike receptor (TLR) activation by LPS. LPS, also called endotoxin, is a Gram-negative bacteria membrane component and its correlation with the atherosclerotic process has been demonstrated long ago in experimental mice models [57], through induction of a low-grade inflammation [58]. A recent metagenomic analysis conducted by Zhou et al. has compared 100 STEMI patients with 49 healthy control and 50 stable CAD subjects, proving that the production of LPS increases in the first group and assuming that it may be due to a raise in intestinal permeability [59]. Kasahara et al. hypothesized that the reduction of atherosclerosis in germ-free mice, despite a significant increase in the plasma and hepatic cholesterol levels, is related to the absence of LPS [60]. Even in this case, however, the data are contradictory and many studies, despite suggesting an increase in inflammation, have failed to demonstrate a statistically significant correlation between LPS and atherosclerosis [61,62].

\section{Pollution, Microbiota and, CAD}

It is well known that one of the most important risk factors for cardiovascular disease is environmental pollution, meaning gas emission of chemical contaminants [79]. This is mainly because exposure to environmental pollutants promotes a systemic vascular oxidative stress reaction and a rise of radical oxygen species which induce endothelial dysfunction, monocyte activation and changes in lipoproteins [80]. Recent studies are revealing how pollution not only directly affects the composition of gut microbiota but also regulates its interaction with the immunity system and production of metabolites involved in atherosclerosis [81].

Exposure to heavy metals is associated with a large number of toxic effects, even on the cardiovascular system [82]. Different studies observed that mice exposed to cadmium have significant changes in gut microbiota, an increase in LPS production and an alteration in bile acid formation $[65,66]$. Some pesticides that contaminate food, water and soil can induce a gut dysbiosis that promotes a pro-inflammatory state and metabolic disorders: exposure to carbendazim, a broad-spectrum benzimidazole fungicide, changes gut microbiota composition and reduces the level of serum lipoprotein lipase, altering lipid metabolism [67]. Particulate matter air pollution, a combination of elements, heavy metals, polycyclic aromatic hydrocarbons and inorganic ions [83], has been associated 
with a spectrum of disease which goes from lung cancer to hypertension $[84,85]$ and can also affect the gut microbiota, leading, again, to an increase in inflammatory response as revealed in studies conducted on murine models $[68,69]$.

\section{Diet, Microbiota, and CAD}

Gut microbiota is involved in the metabolism of dietary sources and rapidly varies according to dietary habits [86]. A growing number of animal and human studies $[45,70,72-75,87,88]$ have reported a close relationship between dietary patterns, gut microbiota, the formation of microbiota-derived metabolites such as TMAO and the development of cardiovascular diseases (Table 6).

In more than 4000 patients undergoing coronary angiography, a strong association was found between fasting plasma levels of TMA and the incidence of adverse cardiovascular events [73]. As previously described, TMA, rapidly oxidized into TMAO, is a gut microbe-dependent metabolite mainly generated from dietary choline and L-carnitine. These dietary components are found in a high variety of foods. The richest sources are meat, fish, poultry, dairy, and eggs, representing predominant food groups of a Western diet. Moreover, elevated TMAO levels were observed over a 4-week interval in individuals consuming a high-fatty diet compared to individuals consuming a low fatty diet [75]. Thus, a Western diet may increase circulating TMAO levels leading to cardiac inflammation and fibrosis, contributing to cardiac dysfunction. Dietary L-carnitine chronic supplementation could accelerate CAD by altering the microbial composition [45]. A recent human study showed that omnivore volunteers significantly generate more TMAO than vegans/vegetarians from oral L-carnitine because of marked increase in gut microbial conversion of $\gamma \mathrm{BB}$ into TMA [72]. Thus, gut microbiota $\gamma \mathrm{BB} \rightarrow$ TMA/TMAO transformation may induce by omnivorous dietary patterns and chronic l-carnitine exposure [72]. A recent study of 345 adults found that in adults with SCA compared with those without SCA, higher levels of Escherichia coli were shown as well as an increased TMAO production [70]. E. coli also correlated with increased LPS absorption and macrophage activation. Gut-derived LPS from E. coli that localizes in human carotid plaque has a potential role as a pro-inflammatory molecule in the atherosclerotic lesion [87]. In mice, compared with the control diet, a diet supplemented with choline enhanced the production of TMAO exacerbating pressure overload-induced heart failure organ [86]. In humans, ingested dietary phosphatidylcholine (lecithin) may also serve as fuel for gut microbiota enhancing the production of TMAO.

On the other hand, the Mediterranean diet is well known to be an optimal dietary prevention of cardiovascular events [71,88]. Specifically, greater adherence to a Mediterranean diet showed a beneficial role on reducing TMAO levels [71]. Moreover, a high-fiber diet increased SCFA levels, including levels of acetate. Interestingly, dietary intake of fiber and supplementation with acetate could modulate cardiac molecular pathways beneficial for cardiovascular function, lowered blood pressure, decreased cardiac hypertrophy and fibrosis, and improved heart function in experimental hypertension [76].

The Mediterranean diet is also rich in fish and flaxseed oil, which have a role in reducing TMAO levels, promoting proliferation of SCFA-producing bacteria, and inhibiting those producing LPS in the gut. A similar effect is also provided by polyphenols-a group of phytochemicals-and beta-glucan, which also reduces blood levels of glucose and cholesterol, providing protection against CVD and diabetes. Both of these molecules abound in the Mediterranean diet [89].

\section{Probiotics, Microbiota and CAD}

As shown by several studies, probiotics exert a protective effect against CAD, mainly through a positive impact over all the main risk factors for atherosclerosis. Recent evidence, in fact, points out that regular consumption of probiotics would provide beneficial effects in lowering low density lipoprotein (LDL) cholesterol, blood pressure, inflammatory mediators, blood glucose levels, and body mass index [90]. 
The composition of intestinal microbiota has been shown to be altered in patients affected by type 2 Diabetes Mellitus and it seems to have a role in inducing insulinresistance [91]. Intake of probiotics-particularly those belonging to Lactobacillus and Bifidobacterium - induce a positive remodulation of gut microbiota that leads to a more resistant intestinal barrier. This stops LPS from translocating to the systemic circulation, thus reducing the release of pro-inflammatory cytokines, as well as glycosylated hemoglobin A1c (HbA1c). At the same time, the correction of dysbiosis promoted by probiotics improves the production of saccharolytic fermentation and SCAFs, which are implicated in the release of glucagonal peptide-1 (GLP-1), a molecule that increases insulin sensitivity [92]. A review on the metabolic effects of probiotics shows how they provide beneficial effects on obesity and insulin resistance, as well as on carbohydrate metabolism, fasting blood glucose and antioxidant status. The authors were also able to find studies that underlie how probiotics and symbiotics improve liver metabolism in patients suffering from non-alcoholic fatty liver disease (NAFLD) [93].

Even dyslipidaemia - another major risk factor for CAD—is positively affected by regular consumption of probiotics. Indeed, with a review focused on the hypocholesterolaemic effect of probiotics, Reis, De Rosa, and Peluzio identify the most studied molecular mechanisms through which they are able to provide a significant improvement in the serum lipid profile. The main ones seem to include deconjunction of bile salts and reduced absorption of intestinal cholesterol, incorporation of cholesterol within the probiotic cell membrane, conversion of cholesterol into coprostanol, and inhibition of hepatic cholesterol synthesis [94]. Despite the fact that all of these mechanisms are still poorly understood, the role of probiotics in reducing bile acid reabsorption and in inhibiting intestinal cholesterol absorption is confirmed by a more recent review by Hassan et al. [95].

Hence, probiotics may soon become a pivotal therapy in preventing CAD, but further studies are needed to assess the effective role of these supplements in inhibiting the developments of atherosclerosis, as well as to identify the specific strains that would test better. Indeed, so far, the choice of the probiotic candidate strain has been almost always empirical. To remedy this, Jiang et al. made an effort to test a specific human-derived Lactobacillus mucosae $A 1$ that was shown to be associated with a high-fiber diet through a metagenomic analysis. The study shows that supplementation with Lactobacillus mucosae A1 in mice on a Western diet attenuates severe lipid accumulation in serum, liver and aortic serum. Despite the fact that the molecular mechanism through which this particular strain provides such an effect is still unclear, the study suggests that diet implementation with Lactobacillus mucosae A1 is effective in treating hyperlipidemia and atherosclerosis in mice [96].

\section{Conclusions}

The literature gathered in our review points out how gut microbiota is closely connected to coronary artery disease, and all the studies confirm a different composition between CAD patients and the healthy population. The latest evidence has shown that this connection is mainly dependent on TMAO, SCFAs and LPS which influence atherosclerosis through metabolic and inflammatory effects. Although microbiota analysis could be potentially useful in predicting cardiovascular risk, the lack of uniformity of results prevents us from using it in clinical practice. One of the reasons for this lack of homogeneity may be the fact that each segment of the GI tract has been shown to have a very peculiar microbiota composition [97], making it even more difficult to identify unique clusters of pathogenic and nonpathogenic microorganisms.

In addition, studies that explore the link between the microbiota and acute coronary syndrome are still scarce, hence we are far from using this analysis in emergency departments as a diagnostic marker. If further expanded, the data we now have available may have mostly a prognostic value, for example, through the identification of clusters associated with classes of risk for CAD. 
Moreover, studies about the association between gut microbiota and pollution show that the gut microbiota homeostasis, which depends on various factors including pollution and lifestyle, is related to cardiovascular risk.

In this setting, modulation of gut microbiota composition in patients with CAD through dietary intervention and probiotics represents a promising therapeutic target. Hence, the modulation of the gut microbiota through lifestyle, treatment and medications could potentially prevent and treat cardiovascular disease.

Author Contributions: Conceptualization, A.P. and F.F.; methodology, T.d.C.; software, M.C.; validation, F.F., A.P.; formal analysis, C.Z.; investigation, P.R., M.C.M.; data curation, M.C.; writingoriginal draft preparation, T.d.C., F.V.; writing-review and editing, E.R.; supervision, M.C.M., F.F., A.P.; project administration, E.R. All authors have read and agreed to the published version of the manuscript.

Funding: This research received no external funding.

Conflicts of Interest: The authors declare that they have no conflict of interest.

\section{References}

1. Nichols, M.; Townsend, N.; Scarborough, P.; Rayner, M. Cardiovascular disease in Europe 2014: Epidemiological update. Eur. Heart J. 2014, 35, 2950-2959. [CrossRef]

2. Fung, T.T.; Rimm, E.B.; Spiegelman, D.; Rifai, N.; Tofler, G.H.; Willett, W.C.; Hu, F.B. Association between dietary atterns and plasma biomarkers of obesity and cardiovas-cular disease risk. Am. J. Clin. Nutr. 2001, 73, 61-67. [CrossRef]

3. The Human Microbiome Project Consortium. Structure, function and diversity of the healthy human microbiome. Nature 2012, 486, 207-214. [CrossRef]

4. Donaldson, G.P.; Lee, S.M.; Mazmanian, S.K. Gut biogeography of the bacterial microbiota. Nat. Rev. Genet. 2016, 14, 20-32. [CrossRef]

5. De Filippo, C.; Cavalieri, D.; Di Paola, M.; Ramazzotti, M.; Poullet, J.B.; Massart, S.; Collini, S.; Pieraccini, G.; Lionetti, P. Impact of diet in shaping gut microbiota revealed by a comparative study in children from Europe and rural Africa. Proc. Natl. Acad. Sci. USA 2010, 107, 14691-14696. [CrossRef] [PubMed]

6. Adolph, T.E.; Mayr, L.; Grabherr, F.; Tilg, H. Paneth Cells and their Antimicrobials in Intestinal Immunity. Curr. Pharm. Des. 2018, 24, 1121-1129. [CrossRef] [PubMed]

7. Ferrer, M.; Méndez-García, C.; Rojo, D.; Barbas, C.; Moya, A. Antibiotic use and microbiome function. Biochem. Pharmacol. 2017, 134, 114-126. [CrossRef] [PubMed]

8. Morrison, D.J.; Preston, T. Formation of short chain fatty acids by the gut microbiota and their impact on human metabolism. Gut Microbes 2016, 7, 189-200. [CrossRef]

9. LeBlanc, J.G.; Milani, C.; de Giori, G.S.; Sesma, F.; van Sinderen, D.; Ventura, M. Bacteria as vitamin suppliers to their host: A gut microbiota perspective. Curr. Opin. Biotechnol. 2013, 24, 160-168. [CrossRef]

10. Klaassen, C.D.; Cui, J.Y. Review: Mechanisms of How the Intestinal Microbiota Alters the Effects of Drugs and Bile Acids. Drug Metab. Dispos. 2015, 43, 1505-1521. [CrossRef]

11. Jandhyala, S.M.; Talukdar, R.; Subramanyam, C.; Vuyyuru, H.; Sasikala, M.; Nageshwar Reddy, D. Role of the normal gut microbiota. World J. Gastroenterol. 2015, 21, 8787-8803. [CrossRef]

12. Nishida, A.; Inoue, R.; Inatomi, O.; Bamba, S.; Naito, Y.; Andoh, A. Gut microbiota in the pathogenesis of inflammatory bowel disease. Clin. J. Gastroenterol. 2018, 11, 1-10. [CrossRef]

13. Kang, Y.; Cai, Y.; Zhang, H. Gut microbiota and allergy/asthma: From pathogenesis to new therapeutic strategies. Allergol. Immunopathol. 2017, 45, 305-309. [CrossRef]

14. Gulas, E.; Wysiadecki, G.; Strzelecki, D.; Gawlik-Kotelnicka, O.; Polguj, M. Can microbiology affect psychiatry? A link between gut microbiota and psychiatric disorders. Psychiatr. Polska 2018, 52, 1-17. [CrossRef]

15. Virili, C.; Fallahi, P.; Antonelli, A.; Benvenga, S.; Centanni, M. Gut microbiota and Hashimoto's thyroiditis. Rev. Endocr. Metab. Disord. 2018, 19, 293-300. [CrossRef]

16. Fabricant, C.G.; Fabricant, J.; Litrenta, M.M.; Minick, C.R. Virus-induced atherosclerosis. J. Exp. Med. 1978, 148, 335-340. [CrossRef]

17. Fabricant, C.G.; Fabricant, J. Atherosclerosis induced by infection with Marek's disease herpesvirus in chickens. Am. Heart J. 1999, 138, S465-S468. [CrossRef]

18. Joshi, C.; Bapat, R.; Anderson, W.; Dawson, D.; Hijazi, K.; Cherukara, G. Detection of periodontal microorganisms in coronary atheromatous plaque specimens of myocardial infarction patients: A systematic review and meta-analysis. Trends Cardiovasc. Med. 2021, 31, 69-82. [CrossRef] [PubMed]

19. Calandrini, C.A.; Ribeiro, A.C.; Gonnelli, A.C.; Ota-Tsuzuki, C.; Rangel, L.P.; Sabachujfi, E.; Mayer, M.P.A. Microbial composition of atherosclerotic plaques. Oral Dis. 2014, 20, e128-e134. [CrossRef] [PubMed] 
20. Izadi, M.; Fazel, M.; Akrami, M.; Saadat, S.H.; Pishgoo, B.; Nasseri, M.H.; Dabiri, H.; SafiAryan, R.; Esfahani, A.A.; Ahmadi, A.; et al. Chlamydia pneumoniae in the atherosclerotic plaques of coronary artery disease patients. Acta Med. Iran. 2013, 51, 864-870. [PubMed]

21. Patel, A.A.; Budoff, M.J. Coronary Artery Disease in Patients with HIV Infection. Am. J. Cardiovasc. Drugs 2015, 15, 81-87. [CrossRef]

22. Jukic, A.; Bozic, D.; Kardum, D.; Becic, T.; Luksic, B.; Vrsalovic, M.; Ljubkovic, M.; Fabijanic, D. Helicobacter pylori infection and severity of coronary atherosclerosis in patients with chronic coronary artery disease. Ther. Clin. Risk Manag. 2017, 13, 933-938. [CrossRef]

23. Fialho, A.; Fialho, A.; Kochhar, G.; Schenone, A.L.; Thota, P.; McCullough, A.J.; Shen, B. Association Between Small Intestinal Bacterial Overgrowth by Glucose Breath Test and Coronary Artery Disease. Dig. Dis. Sci. 2017, 63, 412-421. [CrossRef]

24. Karlsson, F.H.; Fåk, F.; Nookaew, I.; Tremaroli, V.; Fagerberg, B.; Petranovic, D.; Bäckhed, F.; Nielsen, J. Symptomatic atherosclerosis is associated with an altered gut metagenome. Nat. Commun. 2012, 3, 1245. [CrossRef] [PubMed]

25. Emoto, T.; Yamashita, T.; Sasaki, N.; Hirota, Y.; Hayashi, T.; So, A.; Kasahara, K.; Yodoi, K.; Matsumoto, T.; Mizoguchi, T.; et al Analysis of Gut Microbiota in Coronary Artery Disease Patients: A Possible Link between Gut Microbiota and Coronary Artery Disease. J. Atheroscler. Thromb. 2016, 23, 908-921. [CrossRef]

26. Zhu, Q.; Gao, R.; Zhang, Y.; Pan, D.; Zhu, Y.; Zhang, X.; Yang, R.; Jiang, R.; Xu, Y.; Qin, H. Dysbiosis signatures of gut microbiota in coronary artery disease. Physiol. Genom. 2018, 50, 893-903. [CrossRef]

27. Kelly, T.N.; Bazzano, L.A.; Ajami, N.J.; He, H.; Zhao, J.; Petrosino, J.F.; Correa, A.; He, J. Gut Microbiome Associates With Lifetime Cardiovascular Disease Risk Profile Among Bogalusa Heart Study Participants. Circ. Res. 2016, 119, 956-964. [CrossRef] [PubMed]

28. Li, J.; Zhao, F.; Wang, Y.; Chen, J.; Tao, J.; Tian, G.; Wu, S.; Liu, W.; Cui, Q.; Geng, B.; et al. Gut microbiota dysbiosis contributes to the development of hypertension. Microbiome 2017, 5, 1-19. [CrossRef] [PubMed]

29. Cui, L.; Zhao, T.; Hu, H.; Zhang, W.; Hua, X. Association Study of Gut Flora in Coronary Heart Disease through High-Throughput Sequencing. BioMed Res. Int. 2017, 2017, 1-10. [CrossRef] [PubMed]

30. Yoshida, N.; Emoto, T.; Yamashita, T.; Watanabe, H.; Hayashi, T.; Tabata, T.; Hoshi, N.; Hatano, N.; Ozawa, G.; Sasaki, N.; et al. Bacteroides vulgatusandBacteroides doreiReduce Gut Microbial Lipopolysaccharide Production and Inhibit Atherosclerosis. Circulation 2018, 138, 2486-2498. [CrossRef]

31. Toya, T.; Corban, M.T.; Marrietta, E.; Horwath, I.E.; Lerman, L.O.; Murray, J.A.; Lerman, A. Coronary artery disease is associated with an altered gut microbiome composition. PLoS ONE 2020, 15, e0227147. [CrossRef]

32. Stubbs, J.R.; House, J.A.; Ocque, A.J.; Zhang, S.; Johnson, C.; Kimber, C.; Schmidt, K.; Gupta, A.; Wetmore, J.B.; Nolin, T.D.; et al. Serum Trimethylamine-N-Oxide is Elevated in CKD and Correlates with Coronary Atherosclerosis Burden. J. Am. Soc. Nephrol. 2015, 27, 305-313. [CrossRef] [PubMed]

33. Li, X.S.; Wang, Z.; Cajka, T.; Buffa, J.A.; Nemet, I.; Hurd, A.G.; Gu, X.; Skye, S.M.; Roberts, A.B.; Wu, Y.; et al. Untargeted metabolomics identifies trimethyllysine, a TMAO-producing nutrient precursor, as a predictor of incident cardiovascular disease risk. JCI Insight 2018, 3. [CrossRef] [PubMed]

34. Lent-Schochet, D.; Silva, R.; McLaughlin, M.; Huet, B.; Jialal, I. Changes to trimethylamine-N-oxide and its precursors in nascent metabolic syndrome. Horm. Mol. Biol. Clin. Investig. 2018, 35. [CrossRef] [PubMed]

35. Randrianarisoa, E.; Lehn-Stefan, A.; Wang, X.; Hoene, M.; Peter, A.; Heinzmann, S.S.; Zhao, X.; Königsrainer, I.; Königsrainer, A.; Balletshofer, B.; et al. Relationship of Serum Trimethylamine N-Oxide (TMAO) Levels with early Atherosclerosis in Humans. Sci. Rep. 2016, 6, 26745. [CrossRef] [PubMed]

36. Haghikia, A.; Li, X.S.; Liman, T.G.; Bledau, N.; Schmidt, D.; Zimmermann, F.; Kränkel, N.; Widera, C.; Sonnenschein, K.; Haghikia, A.; et al. Gut Microbiota-Dependent Trimethylamine N -Oxide Predicts Risk of Cardiovascular Events in Patients With Stroke and Is Related to Proinflammatory Monocytes. Arter. Thromb. Vasc. Biol. 2018, 38, 2225-2235. [CrossRef] [PubMed]

37. Matsuzawa, Y.; Nakahashi, H.; Konishi, M.; Sato, R.; Kawashima, C.; Kikuchi, S.; Akiyama, E.; Iwahashi, N.; Maejima, N.; Okada, K.; et al. Microbiota-derived Trimethylamine N-oxide Predicts Cardiovascular Risk After STEMI. Sci. Rep. 2019, 9, 1-11. [CrossRef]

38. Li, X.S.; Obeid, S.; Wang, Z.; Hazen, B.J.; Li, L.; Wu, Y.; Hurd, A.G.; Gu, X.; Pratt, A.; Levison, B.S.; et al. Trimethyllysine, a trimethylamine $\mathrm{N}$-oxide precursor, provides near- and long-term prognostic value in patients presenting with acute coronary syndromes. Eur. Heart J. 2019, 40, 2700-2709. [CrossRef] [PubMed]

39. Gao, J.; Yan, K.-T.; Wang, J.-X.; Dou, J.; Wang, J.; Ren, M.; Ma, J.; Zhang, X.; Liu, Y. Gut microbial taxa as potential predictive biomarkers for acute coronary syndrome and post-STEMI cardiovascular events. Sci. Rep. 2020, 10, 1-11. [CrossRef]

40. Tascanov, M.B. Comparisons of microbiota-generated metabolites in patients with young and elderly acute coronary syndrome. Anatol. J. Cardiol. 2020, 24, 175-182. [CrossRef]

41. Seldin, M.M.; Meng, Y.; Qi, H.; Zhu, W.; Wang, Z.; Hazen, S.L.; Lusis, A.J.; Shih, D.M. Trimethylamine N-Oxide Promotes Vascular Inflammation Through Signaling of Mitogen-Activated Protein Kinase and Nuclear Factor-kB. J. Am. Heart Assoc. 2016, 5. [CrossRef] [PubMed]

42. Ma, G.; Pan, B.; Chen, Y.; Guo, C.; Zhao, M.; Zheng, L.; Chen, B. Trimethylamine N-oxide in atherogenesis: Impairing endothelial self-repair capacity and enhancing monocyte adhesion. Biosci. Rep. 2017, 37. [CrossRef] [PubMed] 
43. Chen, M.; Zhu, X.; Ran, L.; Lang, H.; Yi, L.; Ming-Liang, C. Trimethylamine-N-Oxide Induces Vascular Inflammation by Activating the NLRP3 Inflammasome Through the SIRT3-SOD2-mtROS Signaling Pathway. J. Am. Heart Assoc. 2017, 6, e006347. [CrossRef] [PubMed]

44. Geng, J.; Yang, C.; Wang, B.; Zhang, X.; Hu, T.; Gu, Y.; Li, J. Trimethylamine N-oxide promotes atherosclerosis via CD36-dependent MAPK/JNK pathway. Biomed. Pharmacother. 2018, 97, 941-947. [CrossRef]

45. Koeth, R.A.; Wang, Z.; Levison, B.S.; Buffa, J.A.; Org, E.; Sheehy, B.T.; Britt, E.B.; Fu, X.; Wu, Y.; Li, L.; et al. Intestinal microbiota metabolism of 1-carnitine, a nutrient in red meat, promotes atherosclerosis. Nat. Med. 2013, 19, 576-585. [CrossRef] [PubMed]

46. Wang, Z.; Klipfell, E.; Bennett, B.J.; Koeth, R.A.; Levison, B.S.; Dugar, B.; Feldstein, A.E.; Britt, E.B.; Fu, X.; Chung, Y.-M.; et al. Gut flora metabolism of phosphatidylcholine promotes cardiovascular disease. Nat. Cell Biol. 2011, 472, 57-63. [CrossRef] [PubMed]

47. Chen, M.-L.; Yi, L.; Zhang, Y.; Zhou, X.; Ran, L.; Yang, J.; Zhu, J.-D.; Zhang, Q.-Y.; Mi, M.-T. Resveratrol Attenuates Trimethylamine$\mathrm{N}$-Oxide (TMAO)-Induced Atherosclerosis by Regulating TMAO Synthesis and Bile Acid Metabolism via Remodeling of the Gut Microbiota. mBio 2016, 7, e02210-15. [CrossRef]

48. Ding, L.; Chang, M.; Guo, Y.; Zhang, L.; Xue, C.; Yanagita, T.; Zhang, T.; Wang, Y. Trimethylamine-N-oxide (TMAO)-induced atherosclerosis is associated with bile acid metabolism. Lipids Health Dis. 2018, 17, 1-8. [CrossRef]

49. Zhu, W.; Gregory, J.C.; Org, E.; Buffa, J.A.; Gupta, N.; Wang, Z.; Li, L.; Fu, X.; Wu, Y.; Mehrabian, M.; et al. Gut Microbial Metabolite TMAO Enhances Platelet Hyperreactivity and Thrombosis Risk. Cell 2016, 165, 111-124. [CrossRef]

50. Skye, S.M.; Zhu, W.; Romano, K.A.; Guo, C.-J.; Wang, Z.; Jia, X.; Kirsop, J.; Haag, B.; Lang, J.M.; DiDonato, J.A.; et al. Microbial Transplantation With Human Gut Commensals Containing CutC Is Sufficient to Transmit Enhanced Platelet Reactivity and Thrombosis Potential. Circ. Res. 2018, 123, 1164-1176. [CrossRef] [PubMed]

51. Shih, D.M.; Zhu, W.; Schugar, R.C.; Meng, Y.; Jia, X.; Miikeda, A.; Wang, Z.; Zieger, M.; Lee, R.; Graham, M.; et al. Genetic Deficiency of Flavin-Containing Monooxygenase 3 (Fmo3) Protects Against Thrombosis but Has Only a Minor Effect on Plasma Lipid Levels-Brief Report. Arter. Thromb. Vasc. Biol. 2019, 39, 1045-1054. [CrossRef] [PubMed]

52. Roberts, A.B.; Gu, X.; Buffa, J.A.; Hurd, A.G.; Wang, Z.; Zhu, W.; Gupta, N.; Skye, S.M.; Cody, D.B.; Levison, B.S.; et al. Development of a gut microbe-targeted nonlethal therapeutic to inhibit thrombosis potential. Nat. Med. 2018, 24, 1407-1417. [CrossRef] [PubMed]

53. McNelis, J.C.; Lee, Y.S.; Mayoral, R.; Van Der Kant, R.; Johnson, A.M.F.; Wollam, J.; Olefsky, J.M. GPR43 Potentiates $\beta$-Cell Function in Obesity. Diabetes 2015, 64, 3203-3217. [CrossRef]

54. den Besten, G.; Bleeker, A.; Gerding, A.; Van Eunen, K.; Havinga, R.; Van Dijk, T.H.; Oosterveer, M.H.; Jonker, J.W.; Groen, A.K.; Reijngoud, D.-J.; et al. Short-Chain Fatty Acids Protect Against High-Fat Diet-Induced Obesity via a PPARgamma-Dependent Switch From Lipogenesis to Fat Oxidation. Diabetes 2015, 64, 2398-2408. [CrossRef] [PubMed]

55. Vinolo, M.A.; Rodrigues, H.G.; Hatanaka, E.; Sato, F.T.; Sampaio, S.C.; Curi, R. Suppressive effect of short-chain fatty acids on production of proinflammatory mediators by neutrophils. J. Nutr. Biochem. 2011, 22, 849-855. [CrossRef]

56. Aguilar, E.; Leonel, A.; Teixeira, L.; Silva, A.; Silva, J.; Pelaez, J.; Capettini, L.; Lemos, V.; Santos, R.; Alvarez-Leite, J. Butyrate impairs atherogenesis by reducing plaque inflammation and vulnerability and decreasing NFkB activation. Nutr. Metab. Cardiovasc. Dis. 2014, 24, 606-613. [CrossRef] [PubMed]

57. Ostos, M.A.; Recalde, D.; Zakin, M.M.; Scott-Algara, D. Implication of natural killer T cells in atherosclerosis development during a LPS-induced chronic inflammation. FEBS Lett. 2002, 519, 23-29. [CrossRef]

58. Geng, S.; Chen, K.; Yuan, R.; Peng, L.; Maitra, U.; Diao, N.; Chen, C.; Zhang, Y.; Hu, Y.; Qi, C.-F.; et al. The persistence of low-grade inflammatory monocytes contributes to aggravated atherosclerosis. Nat. Commun. 2016, 7, 13436. [CrossRef]

59. Zhou, X.; Li, J.; Guo, J.; Geng, B.; Ji, W.; Zhao, Q.; Li, J.; Liu, X.; Liu, J.; Guo, Z.; et al. Gut-dependent microbial translocation induces inflammation and cardiovascular events after ST-elevation myocardial infarction. Microbiome 2018, 6, 1-17. [CrossRef]

60. Kasahara, K.; Tanoue, T.; Yamashita, T.; Yodoi, K.; Matsumoto, T.; Emoto, T.; Mizoguchi, T.; Hayashi, T.; Kitano, N.; Sasaki, N.; et al. Commensal bacteria at the crossroad between cholesterol homeostasis and chronic inflammation in atherosclerosis. J. Lipid Res. 2017, 58, 519-528. [CrossRef] [PubMed]

61. Fuijkschot, W.W.; Morrison, M.C.; Zethof, I.P.; Krijnen, P.A.; Kleemann, R.; Niessen, H.W.; Smulders, Y.M. LPS-Induced Systemic Inflammation Does Not Alter Atherosclerotic Plaque Area or Inflammation in APOE3*LEIDEN Mice in the Early Phase Up to 15 Days. Shock 2018, 50, 360-365. [CrossRef]

62. Anzulovic-Mirosevic, D.; Barzon, L.; Castagliuolo, I.; Brun, P.; Palu, G.; Zaninotto, M.; Mion, M.M.; Plebani, M.; Dalla-Volta, S. LPS In Patients With Left Ventricular Dysfunction Of Ischemic And Non-Ischemic Origin. Cardiovasc. Hematol. Disord. Targets 2011, 11, 74-78. [CrossRef]

63. Mysara, M.; Vandamme, P.; Props, R.; Kerckhof, F.-M.; Leys, N.; Boon, N.; Raes, J.; Monsieurs, P. Reconciliation between operational taxonomic units and species boundaries. FEMS Microbiol. Ecol. 2017, 93. [CrossRef]

64. Kazemian, N.; Mahmoudi, M.; Halperin, F.; Wu, J.C.; Pakpour, S. Gut microbiota and cardiovascular disease: Opportunities and challenges. Microbiome 2020, 8, 1-17. [CrossRef] [PubMed]

65. Zhang, S.; Jin, Y.; Zeng, Z.; Liu, Z.; Fu, Z. Subchronic Exposure of Mice to Cadmium Perturbs Their Hepatic Energy Metabolism and Gut Microbiome. Chem. Res. Toxicol. 2015, 28, 2000-2009. [CrossRef] [PubMed]

66. Li, X.; Brejnrod, A.D.; Ernst, M.; Rykær, M.; Herschend, J.; Olsen, N.M.C.; Dorrestein, P.C.; Rensing, C.; Sørensen, S.J. Heavy metal exposure causes changes in the metabolic health-associated gut microbiome and metabolites. Environ. Int. 2019, 126, 454-467. [CrossRef] [PubMed] 
67. Jin, C.; Zeng, Z.; Wang, C.; Luo, T.; Wang, S.; Zhou, J.; Ni, Y.; Fu, Z.; Jin, Y. Insights into a Possible Mechanism Underlying the Connection of Carbendazim-Induced Lipid Metabolism Disorder and Gut Microbiota Dysbiosis in Mice. Toxicol. Sci. 2018, 166, 382-393. [CrossRef]

68. Mutlu, E.A.; Comba, I.Y.; Cho, T.; Engen, P.A.; Yazıcı, C.; Soberanes, S.; Hamanaka, R.B.; Niğdelioğlu, R.; Meliton, A.Y.; Ghio, A.J.; et al. Inhalational exposure to particulate matter air pollution alters the composition of the gut microbiome. Environ. Pollut. 2018, 240, 817-830. [CrossRef] [PubMed]

69. Fitch, M.N.; Phillippi, D.; Zhang, Y.; Lucero, J.; Pandey, R.S.; Liu, J.; Brower, J.; Allen, M.S.; Campen, M.J.; McDonald, J.D.; et al. Effects of inhaled air pollution on markers of integrity, inflammation, and microbiota profiles of the intestines in Apolipoprotein E knockout mice. Environ. Res. 2020, 181, 108913. [CrossRef]

70. Baragetti, A.; Severgnini, M.; Olmastroni, E.; Dioguardi, C.; Mattavelli, E.; Angius, A.; Rotta, L.; Cibella, J.; Caredda, G.; Consolandi, C.; et al. Gut Microbiota Functional Dysbiosis Relates to Individual Diet in Subclinical Carotid Atherosclerosis. Nutrients 2021, 13, 304. [CrossRef] [PubMed]

71. De Filippis, F.; Pellegrini, N.; Vannini, L.; Jeffery, I.B.; La Storia, A.; Laghi, L.; Serrazanetti, D.I.; Di Cagno, R.; Ferrocino, I.; Lazzi, C.; et al. High-level adherence to a Mediterranean diet beneficially impacts the gut microbiota and associated metabolome. Gut 2016, 65, 1812-1821. [CrossRef]

72. Koeth, R.A.; Lam-Galvez, B.R.; Kirsop, J.; Wang, Z.; Levison, B.S.; Gu, X.; Copeland, M.F.; Bartlett, D.; Cody, D.B.; Dai, H.J.; et al. 1-Carnitine in omnivorous diets induces an atherogenic gut microbial pathway in humans. J. Clin. Investig. 2018, 129, $373-387$. [CrossRef]

73. Tang, W.W.; Wang, Z.; Levison, B.S.; Koeth, R.A.; Britt, E.B.; Fu, X.; Wu, Y.; Hazen, S.L. Intestinal Microbial Metabolism of Phosphatidylcholine and Cardiovascular Risk. N. Engl. J. Med. 2013, 368, 1575-1584. [CrossRef]

74. Organ, C.L.; Otsuka, H.; Bhushan, S.; Wang, Z.; Bradley, J.; Trivedi, R.; Polhemus, D.J.; Tang, W.W.; Wu, Y.; Hazen, S.L.; et al. Choline Diet and Its Gut Microbe-Derived Metabolite, Trimethylamine N-Oxide, Exacerbate Pressure Overload-Induced Heart Failure. Circ. Heart Fail. 2016, 9, e002314. [CrossRef] [PubMed]

75. Park, J.; Miller, M.; Rhyne, J.; Wang, Z.; Hazen, S. Differential effect of short-term popular diets on TMAO and other cardiometabolic risk markers. Nutr. Metab. Cardiovasc. Dis. 2019, 29, 513-517. [CrossRef] [PubMed]

76. Marques, F.Z.; Nelson, E.; Chu, P.-Y.; Horlock, D.; Fiedler, A.; Ziemann, M.; Tan, J.K.; Kuruppu, S.; Rajapakse, N.W.; El-Osta, A.; et al. High-Fiber Diet and Acetate Supplementation Change the Gut Microbiota and Prevent the Development of Hypertension and Heart Failure in Hypertensive Mice. Circulation 2017, 135, 964-977. [CrossRef] [PubMed]

77. Nicholson, J.K.; Holmes, E.; Kinross, J.; Burcelin, R.; Gibson, G.; Jia, W.; Pettersson, S. Host-Gut Microbiota Metabolic Interactions. Science 2012, 336, 1262-1267. [CrossRef]

78. Xu, J.; Yang, Y. Implications of gut microbiome on coronary artery disease. Cardiovasc. Diagn. Ther. 2020, 10, 869-880. [CrossRef]

79. Vidale, S.; Arnaboldi, M.; Bosio, V.; Corrado, G.; Guidotti, M.; Sterzi, R.; Campana, C. Short-term air pollution exposure and cardiovascular events: A 10-year study in the urban area of Como, Italy. Int. J. Cardiol. 2017, 248, 389-393. [CrossRef]

80. Bourdrel, T.; Bind, M.-A.; Béjot, Y.; Morel, O.; Argacha, J.-F. Cardiovascular effects of air pollution. Arch. Cardiovasc. Dis. 2017, 110, 634-642. [CrossRef]

81. Jin, Y.; Wu, S.; Zeng, Z.; Fu, Z. Effects of environmental pollutants on gut microbiota. Environ. Pollut. 2017, 222, 1-9. [CrossRef]

82. Lamas, G.A.; Navas-Acien, A.; Mark, D.B.; Lee, K.L. Heavy Metals, Cardiovascular Disease, and the Unexpected Benefits of Chelation Therapy. J. Am. Coll. Cardiol. 2016, 67, 2411-2418. [CrossRef]

83. Gao, J.; Wang, K.; Wang, Y.; Liu, S.; Zhu, C.; Hao, J.; Liu, H.; Hua, S.; Tian, H. Temporal-spatial characteristics and source apportionment of PM2.5 as well as its associated chemical species in the Beijing-Tianjin-Hebei region of China. Environ. Pollut. 2018, 233, 714-724. [CrossRef] [PubMed]

84. Zhang, Z.; Zhu, D.; Cui, B.; Ding, R.; Shi, X.; He, P. Association between particulate matter air pollution and lung cancer. Thorax 2019, 75, 85-87. [CrossRef] [PubMed]

85. Huang, K.; Yang, X.; Liang, F.; Liu, F.; Li, J.; Xiao, Q.; Chen, J.; Liu, X.; Cao, J.; Shen, C.; et al. Long-Term Exposure to Fine Particulate Matter and Hypertension Incidence in China. Hypertension 2019, 73, 1195-1201. [CrossRef]

86. David, L.A.; Maurice, C.F.; Carmody, R.N.; Gootenberg, D.B.; Button, J.E.; Wolfe, B.E.; Ling, A.V.; Devlin, A.S.; Varma, Y.; Fischbach, M.A.; et al. Diet rapidly and reproducibly alters the human gut microbiome. Nature 2014, 505, 559-563. [CrossRef] [PubMed]

87. Carnevale, R.; Nocella, C.; Petrozza, V.; Cammisotto, V.; Pacini, L.; Sorrentino, V.; Martinelli, O.; Irace, L.; Sciarretta, S.; Frati, G.; et al. Localization of lipopolysaccharide from Escherichia Coli into human atherosclerotic plaque. Sci. Rep. 2018, 8, 1-8. [CrossRef] [PubMed]

88. Spence, J.D. Diet for stroke prevention. Stroke Vasc. Neurol. 2018, 3, 44-50. [CrossRef] [PubMed]

89. Sanchez-Rodriguez, E.; Egea-Zorrilla, A.; Plaza-Díaz, J.; Aragón-Vela, J.; Muñoz-Quezada, S.; Tercedor-Sánchez, L.; AbadiaMolina, F. The Gut Microbiota and Its Implication in the Development of Atherosclerosis and Related Cardiovascular Diseases. Nutrients 2020, 12, 605. [CrossRef] [PubMed]

90. Thushara, R.M.; Gangadaran, S.; Solati, Z.; Moghadasian, M.H. Cardiovascular benefits of probiotics: A review of experimental and clinical studies. Food Funct. 2016, 7, 632-642. [CrossRef] [PubMed] 
91. Roager, H.M.; Vogt, J.K.; Kristensen, M.; Hansen, L.B.S.; Ibrügger, S.; Mærkedahl, R.B.; Bahl, M.I.; Lind, M.V.; Nielsen, R.L.; Frøkiær, H.; et al. Whole grain-rich diet reduces body weight and systemic low-grade inflammation without inducing major changes of the gut microbiome: A randomised cross-over trial. Gut 2019, 68, 83-93. [CrossRef] [PubMed]

92. Salgaço, M.K.; Oliveira, L.G.S.; Costa, G.N.; Bianchi, F.; Sivieri, K. Relationship between gut microbiota, probiotics, and type 2 diabetes mellitus. Appl. Microbiol. Biotechnol. 2019, 103, 9229-9238. [CrossRef]

93. Sáez-Lara, M.J.; Robles-Sanchez, C.; Ruiz-Ojeda, F.J.; Plaza-Diaz, J.; Gil, A. Effects of Probiotics and Synbiotics on Obesity, Insulin Resistance Syndrome, Type 2 Diabetes and Non-Alcoholic Fatty Liver Disease: A Review of Human Clinical Trials. Int. J. Mol. Sci. 2016, 17, 928. [CrossRef] [PubMed]

94. Reis, S.A.; Conceição, L.L.; Rosa, D.D.; Siqueira, N.P.; Peluzio, M.C.G. Mechanisms responsible for the hypocholesterolaemic effect of regular consumption of probiotics. Nutr. Res. Rev. 2017, 30, 36-49. [CrossRef]

95. Hassan, A.; Din, A.U.; Zhu, Y.; Zhang, K.; Li, T.; Wang, Y.; Luo, Y.; Wang, G. Updates in understanding the hypocholesterolemia effect of probiotics on atherosclerosis. Appl. Microbiol. Biotechnol. 2019, 103, 5993-6006. [CrossRef]

96. Jiang, T.; Wu, H.; Yang, X.; Li, Y.; Zhang, Z.; Chen, F.; Zhao, L.; Zhang, C. Lactobacillus Mucosae Strain Promoted by a High-Fiber Diet in Genetic Obese Child Alleviates Lipid Metabolism and Modifies Gut Microbiota in ApoE ${ }^{-/-}$Mice on a Western Diet. Microorganisms 2020, 8, 1225. [CrossRef] [PubMed]

97. Lkhagva, E.; Chung, H.-J.; Hong, J.; Tang, W.H.W.; Lee, S.-I.; Hong, S.-T.; Lee, S. The regional diversity of gut microbiome along the GI tract of male C57BL/6 mice. BMC Microbiol. 2021, 21, 1-13. [CrossRef] [PubMed] 